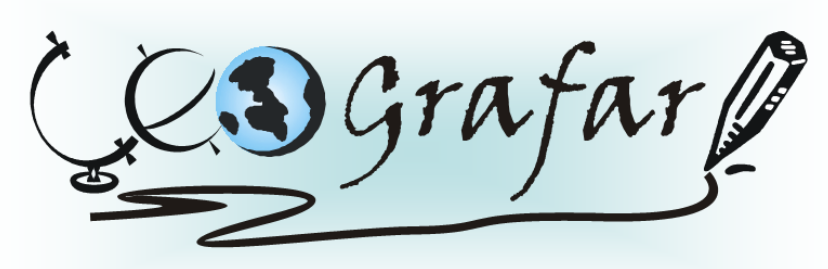

Revista Eletrônica do Programa de Pós-Graduação em Geografia - UFPR

\title{
O TERRITÓRIO MUNICIPAL E A COMPETITIVIDADE ENTRE CIDADES COMO ATRATIVOS CORPORATIVOS: A PERVERSIDADE DOS INCENTIVOS FISCAIS ${ }^{1}$
}

\author{
ESTEVAN RODRIGUES LISKA ${ }^{2}$ \\ EVÂNIO DOS SANTOS BRANQUINHO ${ }^{3}$
}

\begin{abstract}
RESUMO
Algumas transformações marcaram o Brasil durante a década de noventa, como o aumento das trocas internacionais de mercadorias, aumento dos fluxos internacionais de investimento, uma maior descentralização político-administrativa promovida pela constituição de 1988 e a diminuição das políticas de desenvolvimento regionais. No atual período, a competitividade fica restrita por meio das vantagens comparativas entre as cidades, se tornando fundamentais para a aquisição de investimentos. Sob o pretexto de desenvolver a economia local, diversos municípios têm lançado mão da renúncia fiscal para atrair atividades empresariais para seus territórios, em especial no ramo de serviços. Esta pesquisa fará; por meio de entrevistas, observações de diagnóstico, levantamentos bibliográficos e interpretações de dados econômicos e sociais; uma reflexão sobre os resultados da disputa creditícia existente dentro da microrregião de Alfenas, tratando das potencialidades como infraestrutura, das concessões fiscais e das desigualdades econômicas e sociais que se materializam sobre as cidades da região.
\end{abstract}

Palavras-Chave: desigualdades; guerra dos lugares; isenções fiscais; microrregião de Alfenas.

\footnotetext{
${ }^{1}$ Título apresentado originalmente como trabalho de conclusão de curso.

${ }^{2}$ Graduando em Geografia Licenciatura e Bacharelado pela Universidade Federal de Alfenas; email: estevanliska@gmail.com

3 Doutor em Geografia - FFLCH/USP. Professor adjunto de Geografia na Universidade Federal de Alfenas; e-mail: evanio.branquinho@unifal-mg.edu.br
} 


\title{
THE CITY TERRITORY AND THE COMPETITIVENESS AMONG CITIES AND CORPORATIONS AS OF ATTRACTIVES CONDITIONS: THE PERVERSITY OF TAX INCENTIVES
}

\begin{abstract}
Some changes have marked Brazil during the nineties, as the increase of international trade in goods, increased flows of international investment, greater political and administrative decentralization promoted by the 1988 constitution and the decrease of regional development policies. In the current period, the competitiveness is restricted by means of comparative advantage between the cities, becoming central to the acquisition of investments. Under the pretext of developing the local economy, several municipalities have profited from the tax breaks to attract business activities to their territories, especially in the service business. This research will observe and reflect on the results of the dispute within the existing microrregion of Alfenas, through interviews with the secretaries of regional development and local action and literature surveys, dealing with potential, such as infrastructure, tax concessions and industrial and social inequalities that materialize on the region's cities.
\end{abstract}

Keywords: inequalities; microrregion of Alfenas; tax exemptions war places.

\section{INTRODUÇÃO}

Alguns autores como lbañez (2006), têm mostrado que a prática de incentivos fiscais e territoriais às empresas vem se perpetuando sobre o território brasileiro, tornando o desequilíbrio industrial cada vez mais acentuado sobre os espaços. A diminuição de programas históricos de planejamento territorial, como Planos Nacionais de Desenvolvimento, após a adoção do Estado pelas políticas neoliberais vindas do Consenso de Washington gerou efeitos que ampliaram a divisão territorial do trabalho (SANTOS 1997, 1999b; ARAUJO, 1997) e deram origem às concentrações, cada vez maiores, de empresas e indústrias aos espaços competitivos (ARAÚJO, 2000a, 2000b; BECKER e EGLER, 1993; SANTOS e SILVEIRA, 2001; BRANDÃO, 2007) que viraram sinônimos de integração desintegrada (GARCIA, 1994), desintegração interna (RICUPERO, 2000) e construção interrompida (FURTADO, 1992), contudo se observa um esforço à 
retomada do planejamento territorial. A partir de 1996 surge a implementação dos Planos Plurianuais pelo Governo Federal, que tem como objetivo o reordenamento estratégico econômico e funcional sobre o território, porém a sua eficácia aponta restrições como a falta de um gerenciamento fiscal na estrutura administrativa, desigualdades acentuadas de mão de obra qualificada e infraestruturas entre as regiões (MATOS, 2002).

Diante da menor participação do Estado ao planejamento estratégico e funcional do território nos últimos trinta anos e a maior integração da economia brasileira ao mercado mundial, foi escolhida a microrregião de Alfenas, situada no sul de Minas Gerais, porque algumas cidades, como o município de Alfenas, desde o final da década de 90 sofrem grande influência das políticas fiscais das demais cidades, concorrendo de maneira desigual com municípios próximos à rodovia Fernão Dias e à divisa entre os estados de Minas Gerais e São Paulo. As cidades oferecem benefícios às corporações e evocam como recursos atrativos as estradas de rodagem, as isenções fiscais, como do Imposto Predial e Territorial Urbano (IPTU) e do Imposto Sobre Serviços de Qualquer Natureza (ISSQN), concessão de terrenos e construção de distritos industriais.

O crescimento econômico de Minas Gerais tem sido evidente nas últimas décadas e, de modo geral, está em constante expansão. Porém, o crescimento industrial de Minas Gerais não vem ocorrendo de forma geograficamente homogênea. Algumas regiões ou áreas crescem de forma acelerada, enquanto outras crescem de modo lento ou até decrescem (FIGUEIREDO e DINIZ, 2000).

Ao desenvolvimento econômico, os municípios da microrregião de Alfenas se envolvem em uma verdadeira competição para adquirir empresas aos seus territórios. Ao custo de investimentos públicos para a construção de infraestruturas ou modernização de seus arranjos técnicos e logísticos para as empresas, as cidades exaltam suas potencialidades e os oferecem como atrativos à aquisição de investimentos corporativos para dentro de suas fronteiras. Assim, dentro de uma mesma região, os municípios competem entre si pela vinda e instalação de empresas, contribuindo à ampliação das desigualdades econômicas e sociais e da divisão territorial do trabalho.

Especialmente na década de 1990, exemplos de políticas de promoção do desenvolvimento local baseadas nas exigências das empresas que, praticamente, 
obriga os municípios a uma verdadeira guerra fiscal e dos lugares, no sentido de criarem condições espaciais para atração de investimentos, se tornaram comuns. Como "armas" utilizadas pelas cidades pode-se citar a prática de renúncia fiscal e, acessoriamente, a oferta de infraestrutura de circulação e energia, terreno e entre outros.

Os objetivos associados a esse tipo de política baseada na promoção de vantagens competitivas espúrias ou externalidades generalizadas atendem à necessidade dos governos locais de criarem novos postos de emprego no setor privado, atraindo investimentos para regiões com custos de produção mais baixos em consonância ao processo de deslocalização industrial, verificado após a desconcentração industrial do Estado de São Paulo para outras localidades.

A microrregião de Alfenas foi escolhida como análise de estudo, porque, além de fazer parte do processo de desconcentração concentrada (DINIZ, 1994) de indústrias e serviços e possuir uma formação territorial econômica que está sob forte influência do capitalismo industrial do Estado de São Paulo e Rio de Janeiro (FREDERICO, 2009), nas últimas décadas têm-se observado a mobilização de investimentos consideráveis pelo Poder Público em infraestruturas, como a duplicação e reforma da BR491, e aumento de corporações envolvidas em construções de empresas e indústrias para dentro de sua fronteira. No entanto, o aumento desses investimentos tem ocorrido em espaços seletivos (SANTOS, 1999b), que já apresentam demandas técnicas e um potencial logístico sobre o território (SAQUET, 2007), necessários ao estabelecimento de corporações, causando abandonos de investimentos em áreas ditas não produtivas economicamente e tendências a espaços especializados em uma determinada produção econômica (PASSOS e MORO, 2003; CASTILLO e FREDERICO, 2010) princípio da melhor localização (BENKO, 1999).

A justificativa para a prática das concessões de benefícios jurídicos e creditícios pelo Poder Público engloba as necessidades por recursos econômicos, que são extrapoladas pelo viés de maior recolhimento tributário ao longo da ampliação financeira e produtiva local, estadual e nacional que poderão ser convertidos em melhorias sociais, como diminuição do desemprego, e investimentos em infraestruturas. Dessa maneira, no atual período, é cada vez mais diagnosticado o interesse das empresas por territórios que proporcionem a maior quantificação das 
vantagens comparativas (PORTER, 1990; STEVENSON, 2001). Já se verifica espaços propícios a investimentos a partir da especialização produtiva, que moldam a produção para um determinado produto, com o intuito de que os lugares possam competir no mercado e, ao mesmo tempo, excluir outros espaços por meio da competição (SANTOS 1994; BRANDÃO, 2007; CASTILLO, 2008; CANO, 1998).

Este artigo procurará compreender; por meio de entrevistas com os secretários de desenvolvimento e ação regional, empresários, análise de dados econômicos, sociais e observações das viagens realizadas às cidades quanto às infraestruturas; o motivo e as decisões das empresas ao se instalarem em determinado município, porque não em outros, quais os reflexos às cidades que compõem a microrregião de Alfenas e contribuir para a discussão do fenômeno em estudo.

\section{MATERIAIS E MÉTODOS}

Esta pesquisa foi realizada através de levantamentos bibliográficos, entrevistas abertas e semi-estruturadas (QUARESMA e BONI, 2005, p. 75) com os secretários de desenvolvimento econômico e ação regional dos municípios de Alfenas, Machado, Fama e Poços de Caldas, observações de viagens feitas nas cidades de Alfenas, Alterosa, Areado, Fama, Carmo do Rio Claro, Machado, Paraguaçu, Poço Fundo, Pouso Alegre, Varginha e Poços de Caldas, análise e levantamento de dados referentes aos Valores Adicionados Fiscais ${ }^{4}$ (VAF) e

\footnotetext{
${ }^{4} \mathrm{O}$ Valor Adicionado Fiscal (VAF) é um indicador econômico-contábil utilizado pelo Estado de Minas Gerais para calcular o índice de participação municipal no repasse de receita do Imposto sobre Operações relativas à Circulação de Mercadorias e sobre Prestações de Serviços de Transporte Interestadual e Intermunicipal e de Comunicação (ICMS) e do Imposto sobre Produtos Industrializados (IPI) aos municípios mineiros. É apurado pela Secretaria de Estado da Fazenda de Minas Gerais (SEF/MG), com base em declarações anuais apresentadas pelas empresas estabelecidas nos respectivos municípios e corresponde à diferença entre o valor das saídas de mercadorias, acrescido do valor das prestações de serviços tributáveis pelo ICMS e o valor das entradas de mercadorias e serviços recebidos em uma empresa a cada ano civil. Nas hipóteses de tributação simplificada aplicada às microempresas e às empresas de pequeno porte, e em outras situações em que se dispensem os controles de entrada, segundo o mesmo dispositivo, considerarse-á como valor adicionado o percentual de $32 \%$ da receita bruta (MINAS GERAIS, 2011). Tendo em vista as renúncias fiscais concedidas pelas cidades às empresas - IPTU e ISSQN - o VAF se torna fundamental na pesquisa, uma vez que $25 \%$ do montante declarado são devolvidos às cidades através da cota parte do ICMS e pela proximidade ao levantamento dos dados das empresas pela SEF/MG de Alfenas, sendo possível a atualização referente aos valores de produções, onde a obtenção de dados quanto aos Produtos Internos Brutos se mostrou insuficiente às comparações devido à dificuldade de se obter o Produto Interno Bruto (PIB) de uma empresa ou das empresas.
} 
socioeconômicos dos municípios que compõem a microrregião de Alfenas e das cidades Pouso Alegre, Varginha e Poços de Caldas, Figura 1.

Figura 1: Caminho percorrido para se chegar à compreensão do fenômeno em estudo.

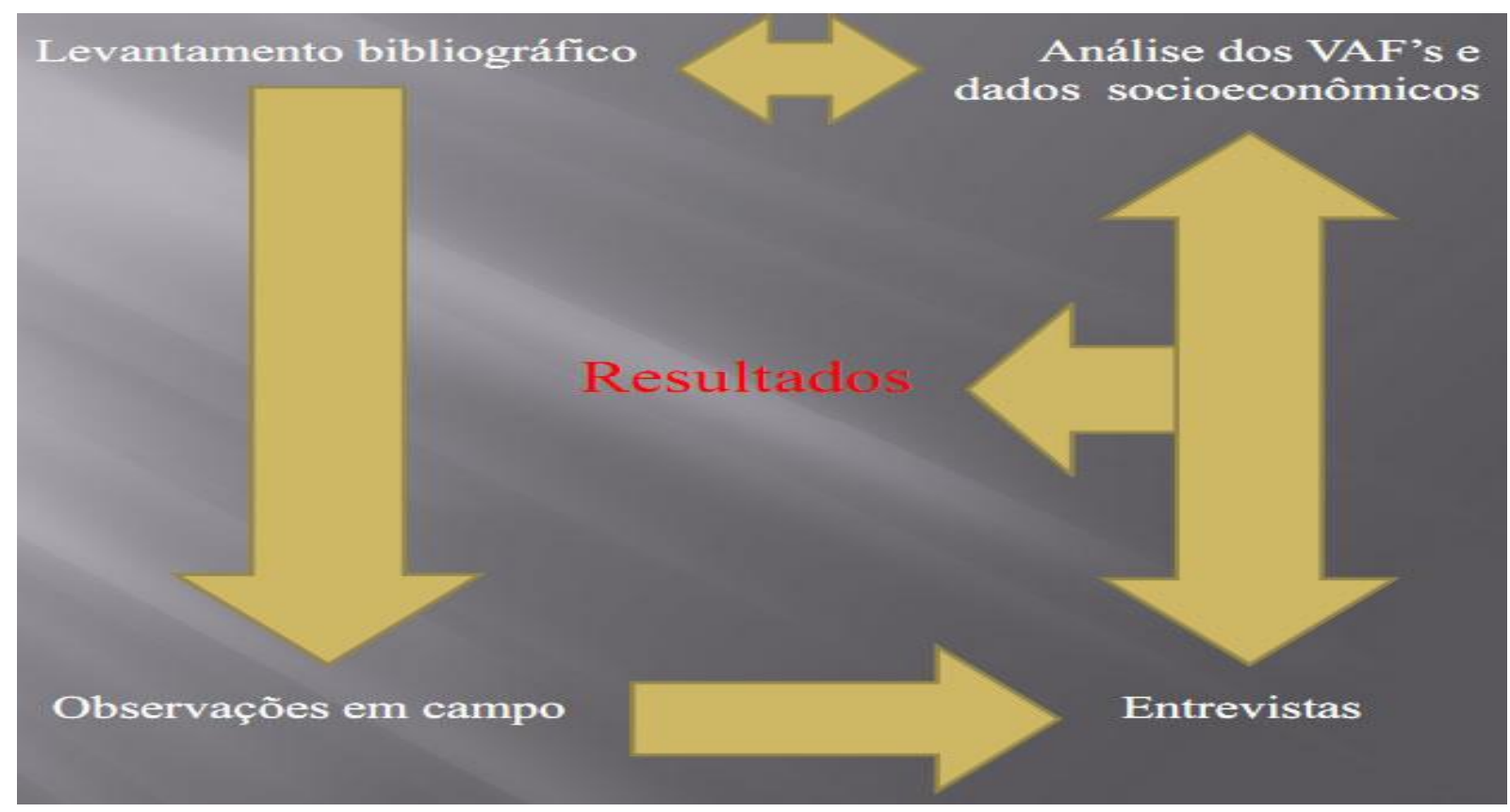

Fonte: os autores.

Foram realizadas pesquisas bibliográficas sobre a temática Guerra Fiscal e dos Lugares, com o objetivo de verificação dos efeitos da prática de renúncia fiscal em outras localidades. Depois, procurou-se investigar bibliografias que tratam sobre as desigualdades espaciais, região competitiva e logística e a lógica das empresas quanto à escolha de suas instalações em espaços que thes possibilitem a maior mais-valia.

A partir das pesquisas bibliográficas, foram realizadas atividades em campo para diagnósticos espaciais sobre o comportamento social - condições de moradia, a distribuição dos empregos e qualificações profissionais dos habitantes - e econômico - infraestruturas ou arranjo técnico e logístico - das cidades.

Realizada essas etapas, iniciou-se a primeira parte das entrevistas, que contou com o apoio dos secretários do desenvolvimento econômico e ação regional de Alfenas e Poços de Caldas, para efeito de se verificar a existência da prática de 
renúncia fiscal dentro da microrregião de Alfenas e também entre as cidades do sul de Minas.

Comprovada a prática de incentivos fiscais municipais às empresas como forma de atrativos, renúncia do Imposto Territorial Predial e Urbano e Imposto Sobre Serviços de Qualquer Natureza por dez anos, iniciou-se levantamento de dados junto à Secretaria de Estado da Fazenda de Minas Gerais quanto aos Valores Adicionados Fiscais dos municípios do sul de Minas (SEF/MG, 2011; PRATES, 2010) e das maiores empresas da cidade de Alfenas. Após, foram realizados levantamentos de dados socioeconômicos para maior abrangência de interpretação do fenômeno em estudo. Esses dados foram cedidos pela Fundação João Pinheiro e Instituto Brasileiro de Geografia e Estatística (BRASIL, 2010a, 2010b; FUNDAÇÃO JOÃO PINHEIRO, 2008).

A segunda fase das entrevistas foi realizada com os secretários do desenvolvimento econômico e ação regional dos municípios de Alfenas, Machado e Fama. A eles foram feitas perguntas sobre quais os incentivos concedidos às empresas, se esses geraram o esperado retorno às expectativas do Poder Público quanto à maior ampliação de suas fontes de recursos econômico-tributárias, quais as maiores empresas da cidade e quais delas ganham alguma forma de isenção, qual a justificativa para a prática da renúncia fiscal, existência de distrito industrial, exigências e locais preferidos pelas empresas.

A terceira fase das entrevistas foi feita em duas grandes empresas de Alfenas, conforme VAF obtido junto à SEEF/MG de Alfenas e informações das entrevistas anteriores, optou-se por adquirir informações referentes a uma empresa que recebeu todos os incentivos municipais e uma que não recebeu benefícios junto à prefeitura. Foram feitas perguntas à gerência e presidência dessas empresas sobre quais os motivos que as trouxeram ao município e quais recursos foram suficientes ao atendimento de seus interesses.

A integração dessas informações possibilitou que esta pesquisa fosse realizada. Dessa forma, a metodologia e os materiais utilizados se tornaram adequados ao estudo, possibilitando comparações e comportamentos entre as cidades e reflexão crítica aos resultados obtidos sobre a microrregião de Alfenas.

\section{A ESCOLHA DA MICRORREGIÃO DE ALFENAS}


A complexidade dos fenômenos que estão conectados a uma essência em comum tem causado reformulações em diversas teorias que envolvem a abordagem do estudo das regiões. A importância da escala de estudo tem sido veementemente debatida entre a comunidade científica e as conceituações remontam desde a institucionalização da Geografia como ciência.

As crescentes transformações no espaço a partir das primeiras décadas do século XX, como a expansão da economia, das finanças, das redes de poder e ao recrudescimento dos nacionalismos, regionalismos e localismos, têm, paradoxalmente, reforçado a compreensão e busca pela escala que permita campos de observação cada vez mais próximos ao pesquisador.

Os impasses e o delineamento de um paradigma eficaz para o estudo das regiões é sempre recorrente, uma vez que cada escala exprime intencionalidades subjetivas diferentes das pessoas com seus espaços (LAVINAS et. al., 1994).

Para Boudon (1991, apud Lavinas et. al., 1994) a intenção de uma escala exprime uma intenção deliberada do sujeito de observar seu objeto. Segundo Lavinas et. al. (1994), o espaço no qual a referência supõe, em geral, a pertinência do objeto ao longo das escalas não fragmenta o resultado final do estudo do objeto, porque os fenômenos que ocorrem em torno de sua essência transitam de maneira a formar uma totalidade, ou seja, o objeto não se fragmenta, mas se complementa ao longo das escalas.

Trata-se de analisar a irreversibilidade do tempo e da escala, partindo-se de um objeto comum a todas as escalas, onde a análise do real se confronte com os paradoxos de ordem/desordem, parte/todo, particular/geral, um/múltiplo de forma que a dimensão fenomenológica se concretize no todo. Sendo assim, a escala só é um problema de proporção, porque, enquanto medida de área, é um problema das ciências exatas.

A partir da análise dos dados referentes ao Valor Adicionado Fiscal e ao tributo Imposto Sobre Circulação de Mercadorias e Serviços obtidos junto à Secretaria de Estado da Fazenda de Minas Gerais e alguns referentes à isenção de impostos municipais, como do Imposto Predial Territorial e Urbano e Imposto Sobre Serviços de Qualquer Natureza, juntamente com a interpretação dos fenômenos/consequências. Concluiu-se, sobre a questão das escalas para análise do objeto, que as perspectivas esperadas ocorrem de maneira semelhante no 
território, todas as cidades renunciam à cobrança do IPTU e ISSQN quando do estabelecimento de novas empresas para dentro de suas fronteiras. Ressalta-se que o teste dos resultados pode sofrer algumas alterações ao longo das escalas, porque existem regiões mais providas de infraestruturas e outros meios de aportes técnicos, gerando-se heterogeneidades, concentrações de empresas e espaços propícios a investimentos, como a proximidade da indústria ao seu consumidor final. Dessa maneira, com os trabalhos em campo foi possível fazer um diagnóstico sobre o comportamento de Alfenas frente à aquisição de empresas para seu território e se constatou as disparidades municipais quanto às infraestruturas, problemas sociais, 0 processo de concentração de indústrias em algumas cidades e a ausência delas em outras.

O levantamento bibliográfico sobre a microrregião de Alfenas e mesorregião sul e sudoeste de Minas em paralelo à interpretação dos dados e observações em campo sobre a microrregião de Alfenas mostraram que a renúncia fiscal do poder público municipal é equivalente aos dos demais municípios da região sul de Minas, demonstrando que as reflexões feitas sobre a microrregião tornam possíveis o diagnóstico de potenciais cidades dormitórios e concorrências desleais que há entre as empresas locais e multinacionais, além de ter demonstrado quem ganha e quem perde no contexto da guerra fiscal e dos lugares e o comportamento da microrregião frente às outras regiões.

\section{USO DO TERRITÓRIO OU DA TERRITORIALIDADE COMO RECURSOS ATRATIVOS?}

As transformações ocorridas no espaço durante as últimas décadas do século XX resultam de um processo de acentuação das transformações econômicas. Cada vez mais os territórios procuram meios para explorar economicamente seus espaços, seja se especializando em determinada produção, seja pelas potencialidades físicas que o território proporciona.

A produção do território, na definição das diferentes formas de territorialidades, ocorre por meio das relações sociais. Os espaços, quanto à exploração e usos internos às suas fronteiras, geram diferentes necessidades e adaptações internas às externalidades, dotando-os de funções e significados 
diferentes. Dessa forma, Poder e Território estão dentro desta análise, não como as únicas formas de entender a utilização do território, mas como elementos que podem contribuir para dar enfoque sobre a produção da territorialidade.

O Poder Local ocorre através das relações que delimitam e reorganizam o poder entre os diferentes movimentos sociais e não é atribuído somente à estrutura municipal, ou normas impostas pelo poder socialmente aceito atribuído aos governantes, mas, principalmente, através de alianças político-econômicas que interferem diretamente nas práticas das políticas públicas municipais no reordenamento territorial (DANIEL, 1988).

O território se torna um palco de relações e processos, nos quais os atores sociais definem suas práticas espaciais de poder e sua territorialidade. Sendo assim, o espaço é considerado como resultado de conflitos de interesses entre forças de poderes diferenciados.

O território é um segmento do espaço delimitado por fronteiras e normas, da apropriação e controle por parte de um grupo social, uma empresa ou uma instituição. O território é, em realidade, um importante instrumento da existência e reprodução. Apresenta, além do caráter político, um nítido caráter cultural, especialmente quando os agentes sociais são grupos étnicos, religiosos ou de outras identidades (ROSENDAHL, 2005).

O caráter político e econômico do território representa aspectos de forte interesse nesta pesquisa. Raffestin (1993) ao discutir as dimensões de poder já apontava para diversas inclinações sobre a territorialidade e o território, no sentido a ser concluído, o espaço ganha novos contornos de poderes que refletem diretamente na divisão social e territorial do trabalho que os territórios assumem ao se inserirem cada vez mais nas redes de comércio econômico.

Assim, Raffestin insere uma contribuição interessante para o território ao discutir a noção de territorialização, desterritorialização e reterritorialização:

Segundo o autor, esse processo ocorre, principalmente, devido a fatores econômicos, em linhas gerais, territorialização implicaria um conjunto codificado de relações, enquanto que a desterritorialização seria, antes de tudo, o abandono do território, podendo também ser interpretada como a extinção dos limites, das fronteiras. Reterritorialização seria o retorno ao território, podendo ocorrer sobre qualquer coisa, do espaço ao dinheiro (SAQUET, 2007, p. 78). 
Na medida em que o Estado ofereça condições para a produção e fluxo de mercadorias parte de seu Poder é perdida para as instituições. O Estado insere recursos econômicos necessários às empresas e, ao mesmo tempo, procura ampliar a oferta de seus espaços em troca de sua injeção ao comércio e maior oferta de empregos para sua população. Na visão do Estado, suas fontes de receitas econômicas podem ser repassadas à sociedade com maior abrangência. No entanto escapa do Estado o controle político financeiro de seu território, porque sua economia fica dependente do sucesso ou fracasso econômico das empresas, que muitas vezes têm suas produções expandidas a outros territórios.

Em um sentido mais amplo, a territorialidade de um lugar se expressa pelo conjunto de mecanismos inseridos a um território. A cultura das pessoas, as normas e as relações de poder que geram condições suficientes às intenções de investimentos. Logo, o papel da territorialidade se traduz na formação de processos identitários locais, considerando sua dinamicidade, pois os elementos que a constituem (o homem-espaço) são susceptíveis de constantes variações no tempo. Essa característica confere à territorialidade a possibilidade de vivências por intermédio de um conjunto de relações emergentes de um sistema tridimensional sociedade, espaço, tempo. Segundo o autor, "a análise da territorialidade só é possível pela apreensão das relações reais recolocadas em seu contexto sóciohistórico e espaço-temporal" (RAFFESTIN, 1993, p. 162).

Santos conclui que o uso do território, já entendido como nexo da territorialidade, determina como se dará a constituição e arranjo das intenções sobre o território:

O uso do território objetiva a formação sócio-espacial e determina o arranjo espacial dos objetos e equipamentos necessários à organização das relações entre os indivíduos e destes com as instituições presentes no lugar, reunidos numa mesma lógica interna todos os seus elementos: homens, empresas, instituições sociais e jurídicas e formas geográficas (SANTOS, 1999a, p. 272).

A legislação tributária vale, em princípio, nos limites do território da pessoa jurídica que edita a norma. No âmbito federal a norma vale apenas dentro do território brasileiro, no âmbito municipal, dentro do município e, assim, sucessivamente. Todavia a norma pode alcançar sujeitos passivos fora do Estado 
Federal, do município ou estado, como prevê o art. 102 do Código Tributário Nacional:

\begin{abstract}
A legislação tributária dos Estados, do Distrito Federal e dos municípios vigora, no País, fora dos respectivos territórios, nos limites em que the reconheçam extraterritorialidade os convênios de que participem ou de que disponham esta ou outras leis de normas gerais expedidas pela União. Entretanto, o Código Tributário Nacional (Art. 102) admite a extraterritorialidade da norma tributária, excepcionalmente, desde que haja convênio entre as pessoas jurídicas de Direito Público interno interessadas (Distrito Federal, Estados e Municípios), ou desde que existam tratados ou convenções firmados pela União (ALONSO, 2010, p. s.n).
\end{abstract}

Usando-se da constituição brasileira ficou mais claro compreender o sentido da territorialidade e o nexo de extraterritorialidade.

A territorialidade abrange diversos elementos sobre o território, até que ponto interessa às empresas a cultura local e todas as intencionalidades realizadas ao território - infraestruturas e as normas locais?

\title{
5 A BUSCA POR ESPAÇOS COMPETITIVOS
}

No território brasileiro, a modernização ocorrida em diversos seguimentos industriais e comerciais, principalmente a partir da década de 1990, tem causado perturbações nas noções tradicionais de região e de rede. Da análise dessa situação decorrem investimentos do Estado em infraestruturas que comportem cada vez mais as exigências das empresas, frente a uma produção cada vez mais exigente pela consolidação do encurtamento espaço-tempo.

Segundo Castillo e Frederico, a concepção de competitividade designa também uma condição dos lugares e regiões. Para os autores,

A distribuição desigual de densidades materiais e normativas no território confere diferentes graus de competitividade às regiões para determinados tipos de produtos e, por conseguinte, a alguns agentes produtivos que nelas atuam e que delas fazem parte. Esse tem sido, aliás, o fundamento lógico e prático dos decantados Arranjos Produtivos Locais, clusters e congêneres, cuja profusão, com o apoio de poderes públicos locais, é notória, trazendo benefícios duvidosos para os lugares e prejuízos certos para o conjunto do território e da sociedade nacionais, como bem apontaram geógrafos e economistas, ao mesmo tempo em que se revelam funcionais ao regime de acumulação vigente (CASTILLO e FREDERICO, 2010, p. 18). 
Outro aspecto da reafirmação do uso da territorialidade como recurso é o fenômeno que Santos (1999c) chamou de guerra dos lugares, que utilizou para falar das especialidades dos municípios ao vender seus territórios como mercadorias às grandes empresas multinacionais. Haesbaert fala da evidência da territorialidade neste período, ao contrário do seu desaparecimento:

[...] os municípios para oferecer as condições mais vantajosas em termos de subsídios, infraestrutura, mão-de-obra e imagem, mostram que o espaço e o território - em vez de diminuir sua importância, muitas vezes amplia seu papel estratégico, justamente por concentrar ainda mais, em pontos restritos, as vantagens buscadas pelas grandes empresas e pela intensificação da diferenciação de vantagens oferecidas em cada sítio (HAESBAERT, 2004, p. 187).

No atual período é cada vez mais diagnosticado o interesse das empresas por territórios que proporcionem a maior quantificação das vantagens comparativas (PORTER, 1990; STEVENSON, 2001). Os espaços procuram se especializar em uma determinada atividade e mobilizam recursos econômicos à construção de infraestruturas às empresas e, por vezes, capacitar profissionalmente sua população oferecendo cursos de capacitação profissional, cujas temáticas são àquelas voltadas à necessidade e produção característica da localidade. Exemplos são os cursos gratuitos oferecidos pelas prefeituras como técnico em manutenção de computadores, cursos de informática básica, técnico agrícola, derriçador de café, tratorista e entre outros.

A capacitação é uma experiência capaz de produzir uma mudança permanente no indivíduo, melhorando sua capacidade de desempenhar um determinado cargo e aumentar sua interatividade e produtividade no ambiente de trabalho. Pensando em melhorar a qualidade do resultado esperado pelas empresas do Município, a Secretaria Municipal de Desenvolvimento Econômico e Ação Regional desenvolveu um trabalho de pesquisa para identificar quais as necessidades das empresas locais quanto à capacitação de pessoal. Os resultados são a base usada pela prefeitura para implantação de novas políticas públicas voltadas para a melhoria e desenvolvimento dos centros de profissionalizações gratuitos oferecidos na cidade (PREFEITURA MUNICIPAL DE ALFENAS, 2011, p. s.n).

Como sugere Castillo e Frederico (2010, p.19) a despeito de importantes teorias históricas que declaram o contrário, considera-se que a 
aumento dos fluxos materiais e informacionais, decorrente da gradativa mundialização da produção, da prestação de serviços e do consumo, pelo menos para alguns setores e circuitos econômicos. A unicidade planetária das finanças, acompanhada por grande diversificação de formas e maior penetração nos tecidos sociais e na vida econômica, também é uma insígnia das transformações recentes do capitalismo.

Não diferente das opções que asseguram aos territórios a aquisição de empresas, resta-lhe incrementar ações impostas por elas aos seus espaços. Um dos atributos que a região necessita para se tornar competitiva é dispor de um eficiente meio logístico.

Sobre a importância da logística como ferramenta de apoio às cidades e regiões, Castillo e Frederico (2010, p. 21) se aproximam da noção apresentada pelas exigências das empresas:

[...] a noção de logística passou a ser um dos pontos centrais do ordenamento dos fluxos que perpassam os diversos circuitos espaciais produtivos. A ideia de logística, na migração do sentido militar para o empresarial, tornou-se um termo polissêmico, empregado para designar variadas formas de prestação de serviços, condições gerais de produção, setor de atividade econômica e ramo de investimentos públicos. $\mathrm{Na}$ tentativa de compreender o termo em sua dimensão geográfica, propomos defini-lo como o conjunto de competências infraestruturais (transportes, armazéns, terminais multimodais, portos secos, centros de distribuição etc.), institucionais (normas, contratos de concessão, parcerias público-privadas, agências reguladoras setoriais, tributação etc.) e operacionais (conhecimento especializado detido por prestadores de serviços ou operadores logísticos) que, reunidas num subespaço, podem conferir fluidez e competitividade aos agentes econômicos e aos circuitos espaciais produtivos. Trata-se da versão atual da circulação corporativa.

É cada vez mais visível no território aglomerações de empresas, pessoas e serviços em espaços especializados a atender demandas características à eficiência e otimização das técnicas. Nesse caso, toda a territorialidade pressupõe intenções de diversos agentes envolvidos no planejamento dos espaços, que cada vez mais concentram esforços para torná-los dinâmicos e modernos aos fluxos de mercadorias e serviços.

Por outro lado, todas as intenções de investimentos ficam retidas aos lugares espacialmente competitivos, assim se exclui regiões ditas não produtivas ou que não se adéquam às determinações das empresas e dos fluxos comerciais e econômicos, causando abandono de espaços e exaltação de interesses corporativos em outros. Como se verá em outros tópicos, existem cidades que dependem dos repasses de 
ICMS e de suas propriedades paisagísticas como formas de sobrevivência financeira frente às outras.

\section{A ESCOLHA POR ESPAÇOS COMPETITIVOS PELAS CORPORAÇÕES}

Cabe ao Poder Público equacionar, para entender sua complexidade e a necessidade de planejar os serviços, a infraestrutura, os equipamentos públicos e as atividades administrativas em geral. Planejar é se antever o futuro e exige decisões sobre o que fazer e em que ordem de prioridades, tendo-se em consideração as necessidades e os recursos disponíveis.

Com essa perspectiva, o Estado está presente ou ausente conforme a combinação de interesses envolvidos em termos de preocupações com 0 crescimento da participação produtiva dos espaços, no âmbito do conjunto econômico. Com isso amplia-se ainda mais a significação desse tipo de empresa para a estruturação econômica regional e sua respectiva organização espacial.

Ao considerar os aspectos que envolvem a atuação de grandes empresas na busca de vantagens comparativas de um espaço, o caráter geográfico manifesta-se nas estruturas desses espaços - modelados, remodelados e transformados. Tal realidade pode ser percebida numa visão que integra as vertentes: econômica, social e ambiental sob o foco regional (PASSOS e MORO, 2003).

Benko (1999) salienta que as empresas ostentam a mais-valia e, dessa forma, interessa a elas o principio da melhor localização. Esse princípio está conectado aos custos de transportes, obtenção de matéria-prima, projeção futura das localidades a investimentos, dentre outros. Para ele, o conjunto desses fatores responde às explosões espaciais de empresas.

Porém, não se pode aplicar interesses homólogos às necessidades das empresas, Benko (1999) atenta para esse questionamento. A decisão de alocar uma atividade empresarial se torna relevante, mas o local necessita ser adequado e garantir um número mínimo de clientes - quando da empresa ser de pequeno porte e infraestruturas que possibilitem o resgate de matérias primas e distribuição dos produtos. As concentrações empresariais para uma localidade geralmente são explicadas a partir do aumento de fornecedores e clientes que, com o passar do 
tempo, geram receitas financeiras futuras ao longo da cadeia produtiva das localidades.

Cada fator influencia na tomada decisão ao estabelecimento da empresa em um território e varia conforme seus interesses e suas necessidades. Assim, cabe ao empreendedor alçar as suas necessidades imediatas.

Bernardes e Marcondes (2000) apud Toledo et. al. (2007, p. 18) sugerem algumas funções administrativas para a classificação dos fatores relevantes quanto à escolha da localização de um estabelecimento de pequeno a médio porte:

Fatores relacionados às vendas: procurar analisar as exigências do cliente (deslocamento do cliente, facilidade de encontrar o produto procurado, prazo de entrega e instalações de boa aparência) e adaptar-se sempre a elas;

Fatores relacionados à produção: relacionam-se aos aspectos internos da empresa (estrutura do processo produtivo, áreas disponíveis para futuras expansões e planta das instalações);

Fatores relacionados às compras: comumente esses fatores são de grande número (logística de insumos e produtos acabados e proximidade com fornecedores);

Fatores relacionados às finanças: custos do imóvel e das instalações;

Fatores relacionados à mão-de-obra: facilidade em encontrar mão-deobra especializada, treinamento dos colaboradores, cultura interiorizada e apoio dos sindicatos.

Na concepção de Chopra e Meindl (2004) apud Toledo et. al. (2007, p. 21-22), existem alguns fatores que influenciam nas decisões de localização das empresas de médios e grandes portes:

Fatores estratégicos: a estratégia competitiva influencia muito na decisão de instalação, empresas que priorizam custos tendem a se instalar em locais mais baratos, as que priorizam responsabilidade se instalam perto dos mercados consumidores ou locais de fácil acesso e as que têm como objetivo o mercado internacional se localizam em diversos países do mundo.

Fatores tecnológicos: as tecnologias de produção disponíveis exercem um impacto significativo nas decisões de localização. No caso de economia de escala expressiva, a melhor decisão corresponde a optar por poucos locais com alta capacidade; na situação inversa, com custos fixos baixos, as instalações devem ser em vários locais.

Fatores macroeconômicos: à medida que o comércio foi se globalizando, os fatores macroeconômicos (impostos, tarifas, taxas de câmbio e outros fatores econômicos) se tornaram vitais para o sucesso ou fracasso de uma cadeia de suprimentos. Os incentivos fiscais oferecidos por muitas regiões que estão procurando o desenvolvimento local, na maioria das vezes, constituem o fator-chave na decisão de instalação de uma empresa. Países em desenvolvimento geralmente criam zonas de livre-comércio, onde taxas e tarifas são reduzidas desde que a produção seja essencialmente destinada à exportação. As empresas internacionais apreciam esse 
incentivo, principalmente pela oportunidade de explorar a mão-de-obra barata local. As flutuações da taxa de câmbio, a estabilidade política do país em questão e a disponibilidade de boa infraestrutura também são fatores que impactam a decisão de localização.

Fatores competitivos: para escolher o local onde se instalará, a empresa deve considerar a estratégia, o tamanho e local dos concorrentes. A maneira como as empresas competem entre si e fatores externos como mão-de-obra e matéria-prima geralmente as obrigam a ficar perto de seus concorrentes. Outros fatores que levam as empresas a se instalarem perto umas das outras são os benefícios por geração de demanda e infraestrutura, que várias empresas do mesmo setor têm a condição de proporcionar, mais do que se estivessem isoladas.

Tempo de resposta ao cliente e presença local: empresas cujos clientes exigem tempo rápido de resposta precisam localizar-se perto deles. Em contrapartida, as companhias cujos clientes toleram um tempo de resposta mais longo exigem menos locais e podem se concentrar no aumento da capacidade de cada local.

Custos de logística e instalações: levam em conta os custos de estoque e de transporte tanto de entrada (contraídos na chegada de material à instalação) como de saída (contraídos ao enviar material de uma instalação).

A escolha por lugares competitivos estão além das necessidades das empresas, porque aperfeiçoam ao máximo os ganhos. Nesse jogo de interesses entre Poder Público e corporações, ambos saem vitoriosos às obtenções de maiores recolhimentos financeiros. De um lado, o Estado procura aumentar as fontes de receita tributária sobre seu território. Do outro lado, as empresas encontram meios para explorar a maior mais-valia sobre o uso do espaço e das territorialidades. $O$ consenso à busca da maior ampliação financeira é evidente e revela a dependência econômica do Poder Público junto às corporações à sua própria existência enquanto instituição que procura alcançar o bem-estar social. Contudo, os municípios se envolvem em verdadeiras batalhas à conquista da melhoria econômica e se utilizam de suas atribuições administrativas, jurídicas, potencialidades físicas - como infraestruturas - e sociais - a cultura local, por exemplo - de seus espaços para a aquisição de novas plantas industriais e comerciais.

\section{APRESENTAÇÃO DA ÁREA EM ESTUDO}

O Estado de Minas Gerais, de acordo com dados da Fundação João Pinheiro (2008) e Rosado et. al. (2009), é marcado por grandes diferenças regionais e microrregionais no que tange às questões sociais e econômicas. 
Segundo o Instituto Brasileiro de Geografia e Estatística (IBGE), a microrregião de Alfenas é composta por doze municípios: Alfenas, Alterosa, Areado, Carmo do Rio Claro, Carvalhópolis, Conceição da Aparecida, Divisa Nova, Fama, Machado, Paraguaçu, Poço Fundo e Serrania. É uma das microrregiões de Minas Gerais, pertencente à mesorregião sul e sudoeste de Minas. Possui uma área total de 4.987,469 $\mathrm{Km}^{2}$ e faz fronteiras limítrofes com as microrregiões de Andrelândia, Itajubá, Passos, Poços de Caldas, Pouso Alegre, Santa Rita do Sapucaí, São Lourenço, São Sebastião do Paraíso e Varginha. A mesorregião comporta aproximadamente 2,5 milhões de habitantes espalhados em 146 municípios (BRASIL, 2010b).

A microrregião de Alfenas se destaca quanto à criação de empregos, saneamento básico, postos de saúde e tem contribuído de maneira significativa ao Produto Interno Bruto (PIB) do Estado de Minas Gerais ${ }^{5}$. Algumas de suas cidades, como Machado e Alfenas, demonstraram, segundo dados socioeconômicos de Minas Gerais em 2008, crescimentos consideráveis de geração de empregos, respectivamente aumentaram seus índices em 24,37\% e 17,9\%.

Segundo a contagem de população de 2007 (BRASIL, 2010b), a microrregião possui 220.129 habitantes, Alfenas e Machado possuem, respectivamente, 71.628 e 37.567 habitantes e os demais municípios contam com populações que não ultrapassam 20.000 habitantes, sendo Fama o correspondente com menor habitação - 2.219 habitantes. No primeiro semestre de 2008 o município de Machado possuía - maior PIB per capita da microrregião $(\mathrm{R} \$ 15.861,07)$, seguido de Alfenas $(\mathrm{R} \$ 13.435,55)$, Carmo do Rio Claro $(\mathrm{R} \$ 12.109,58)$, Conceição da Aparecida $(R \$ 11.642,95)$, Fama $(R \$ 11.918,52)$ e Paraguaçu $(R \$ 10.499,39)$. Os demais municípios possuíam valores entre 5.000 e 10.000 Reais e demonstra que a microrregião de Alfenas - $R \$ 124.808 .83$ - teve um PIB per capita superior a de muitas regiões brasileiras (BRASIL, 2010a).

\footnotetext{
${ }^{5}$ A observação durante as viagens às cidades que compõem a microrregião de Alfenas demonstrou que Alfenas e Machado concentram essas virtudes. Foi possível destacar o envolvimento de outras cidades ao custeio com transportes de suas populações aos centros de saúde de Alfenas e Machado, porque os municípios como, por exemplo, Fama e Alterosa dispõem de unidades médicas com poucos instrumentos médico-hospitalares. Também foi possível destacar que Alfenas e Machado retêm os serviços que exigem um grau de especialização maior: empresas ligadas ao turismo, às finanças, à manutenção de máquinas industriais e ao ensino superior.
} 
Em alguns municípios da microrregião a contribuição da agropecuária ultrapassa 40\%: Conceição da Aparecida $(50,4 \%)$ Carmo do Rio Claro $(46,8 \%)$, Fama (45,3\%) e Divisa Nova (42,9\%). A Indústria tem contribuição expressiva em quatro dos doze municípios: Alfenas (33,3\%), Machado (33,0\%), Paraguaçu $(27,9 \%)$ e Serrania (20,8\%). A maioria de suas indústrias está relacionada ao beneficiamento de produtos agrícolas como laticínios, torrefadoras e produtos de insumos (BRASIL, 2010a).

No entanto, ao observar os valores adicionados por setores econômicos, Gráfico 1, o setor de serviços se apresenta ser a especialização econômica da microrregião, sendo as cidades de Alfenas, Machado, Paraguaçu, Carmo do Rio Claro e Poço Fundo responsáveis pelos maiores números.

Gráfico 1 - Valor Adicionado Fiscal entre os setores econômicos da microrregião de Alfenas. Ano base 2009.

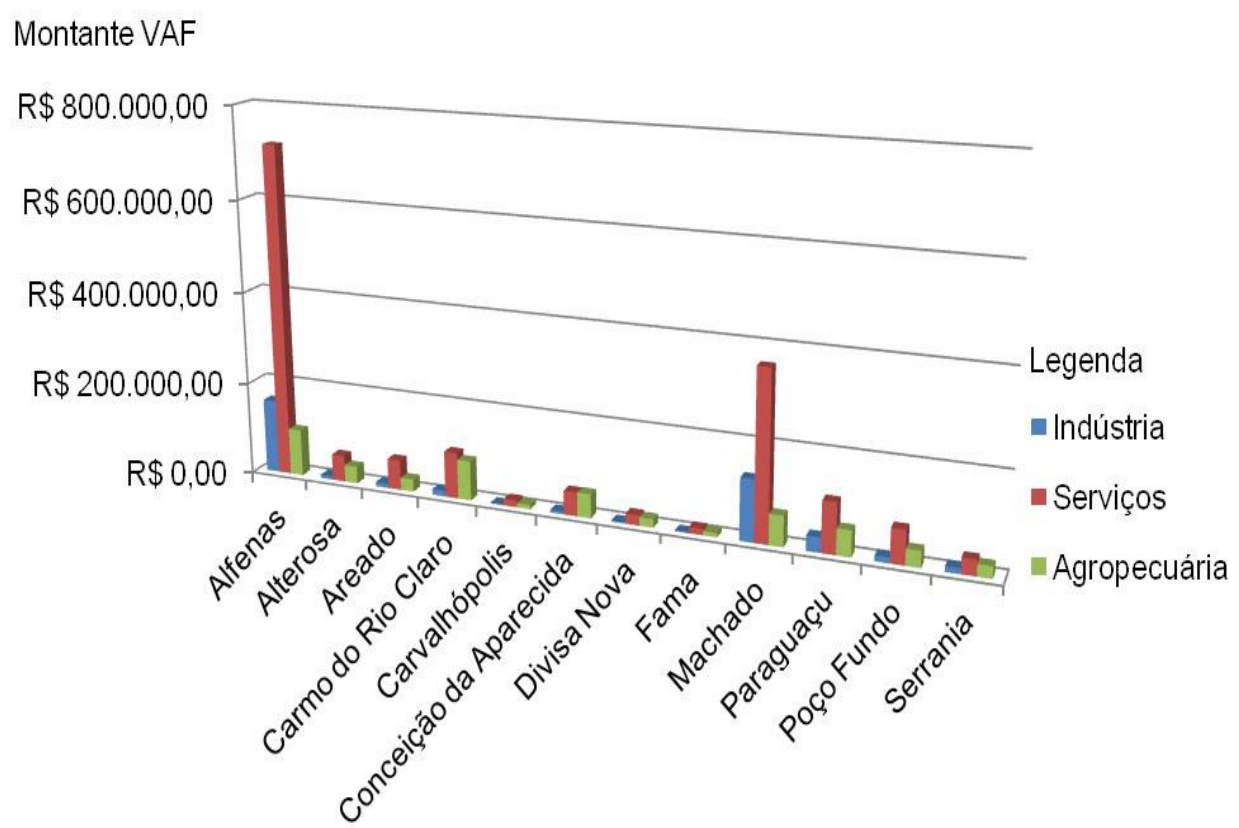

Adaptado de: IBGE, em parceria com os Órgãos Estaduais de Estatística, Secretarias Estaduais de Governo e Superintendência da Zona Franca de Manaus - SUFRAMA.

Do ponto de vista do Valor Adicionado Fiscal, a microrregião de Alfenas é a quinta maior no Estado de Minas Gerais, Gráfico 2. As microrregiões de Poços de Caldas $(20,69 \%)$, Varginha $(18,22 \%)$ e Pouso Alegre $(16,75 \%)$ representam a maior parte do VAF (57\%) gerado pela mesorregião sul e sudoeste de Minas. Entretanto, a expectativa é que essa participação venha a crescer ao longo dos próximos anos em 
função dos investimentos anunciados pelas empresas, conforme noticiado em diversas fontes - boletins do Ministério do Desenvolvimento e Secretaria do Desenvolvimento de Minas Gerais.

\section{Gráfico 2 - Participação de cada microrregião no total de Valor Adicionado Fiscal} dentro do Estado de Minas Gerais em 2007.

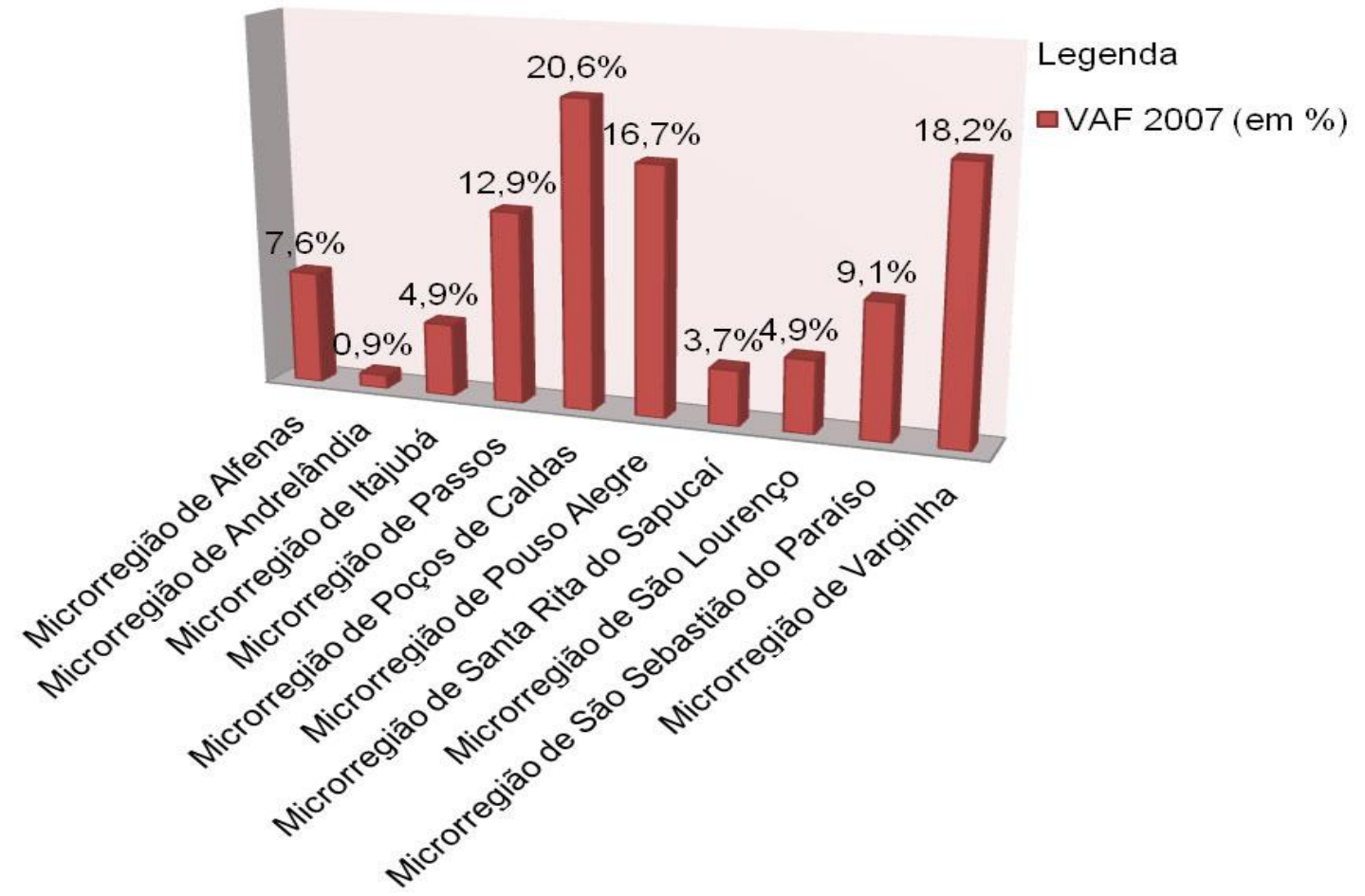

Adaptado de: PRATES (2010).

As mesorregiões apresentaram um crescimento econômico significativo entre os anos 2000 e 2010, porém o norte do estado continua a apresentar um dinamismo econômico bastante inferior, ainda que tenha alcançado taxas de crescimento semelhantes às demais regiões (PRATES, 2010).

Segundo o secretário de Estado de Desenvolvimento Econômico de Minas Gerais, Raphael Guimarães Andrade, o crescimento das microrregiões foi generalizado, tanto nos setores econômicos quanto nas diferentes regiões de Minas Gerais. Para ele, o crescimento do número de empregos formais é sempre um fator animador para quem trabalha pelo desenvolvimento do Estado, já que novos postos de empregos significam mais dinheiro em circulação e melhores condições de vida para milhares de mineiros. 


\section{RESULTADOS E DISCUSSÕES}

A busca pelas empresas por territórios que oferecem condições de infraestruturas e de benefícios creditícios se aproxima às explicações de explosões espaciais de empresas (BENKO, 1999) de maneira pontual na microrregião de Alfenas. Alguns municípios, como Machado e Alfenas, que desfrutam de suporte significativo para a otimização do espaço-tempo das informações e trocas de mercadorias, adicionada às desgarradas concessões de benefícios e favores às empresas, mantém suas vitórias na guerra dos lugares e conquistam novas plantas industriais e redes de serviços (SANTOS 1994; BRANDÃO, 2007; CASTILLO, 2008; CANO, 1998).

Dentro da microrregião, Alfenas, Machado e Paraguaçu competem entre si e são considerados pólos industriais e de serviços. No entanto, disputam pela produção da agricultura e pecuária Alfenas, Carmo do Rio Claro, Machado, Paraguaçu, Conceição da Aparecida, Poço Fundo e Alterosa e exclusão de outros municípios, que não encontram espaço para competir economicamente e se especializam no setor de serviços locais, como Divisa Nova, Carvalhópolis e Fama, Gráfico 1, sendo dependentes de ações sociais ${ }^{6}$, do resgate tributário de sua cota parte da fatia do ICMS - Lei $18.030^{7}$, do turismo e datas festivas, principais fontes de recursos financeiros para as suas manutenções.

A falta de um planejamento econômico e social eficiente obriga as cidades a competir entre si por maiores fontes de recursos econômicos para as suas manutenções sociais, empregos para a população, e investimentos em infraestruturas - aumento de suas fontes de receita econômico-tributárias. Dessa

\footnotetext{
${ }^{6}$ Em comparação aos dados populacionais das cidades, BRASIL (2010b), Relatório Consolidado do Bolsa Família, MS/SE/DATASUS de 2011, e conforme observado em trabalho de campo: considerouse que; para uma média de quatro pessoas por família, $19,4 \%$ da população de Fama, $24,1 \%$ da população de Carvalhópolis e $20,6 \%$ da população de Divisa Nova; parcela significativa de suas populações recebe Bolsa Família.

${ }^{7}$ As alterações trazidas pela atual legislação - Lei 18.030 - em relação às anteriores foram: redução no critério de distribuição do Valor Adicionado Fiscal, no critério população - relação população Município/Estado, na receita própria e nos municípios mineradores. Houve ainda a criação de novos critérios, como recursos hídricos, municípios sede de estabelecimentos penais, esportes, turismo, ICMS solidário (com o maior percentual) e mínimo per capita. As mudanças ao repasse dos recursos aos municípios representam uma tentativa do Estado de Minas Gerais em minimizar concentrações de riquezas. Observa-se que, desde a Lei 13.803 , soluções alternativas para tentar diminuir as desigualdades territoriais foram discutidas e, por meio da lei, procurou-se de maneira que os municípios com arrecadações de ICMS per capita abaixo de 1/3 do total do estado, por exemplo, tenham maiores repasses do total arrecado pelo estado.
} 
maneira, Alfenas, Machado e Paraguaçu; por possuírem condições infraestrututurais de suporte à fluidez de mercadorias e serviços mais eficientes e estarem mais próximas ao eixo comercial entre os centros comerciais e econômicos de Belo Horizonte e São Paulo; têm a tendência para aglomerar comércios, serviços e indústrias em seus espaços, enquanto algumas a se especializar no setor agropecuário e outras a ser refúgio de empresas domésticas ou servirem de cidades dormitórios aos pólos econômicos e industriais (SANTOS, 1979), porque invocam as mesmas concessões de benefícios e favores às empresas.

Os investimentos corporativos se concentram em algumas cidades da microrregião e; pois, apesar do crescimento econômico ser generalizado; incidem aos lugares que dispõem de um arranjo técnico e econômico mais eficiente que os outros. Dessa forma, os espaços competitivos continuam, por inércia, a aglomerar empresas e a florescer economicamente, Gráfico 3.

Gráfico 3 - Valor Adicionado Fiscal entre os municípios da microrregião de Alfenas. Ano base 2004 a 2009.

Montante VAF

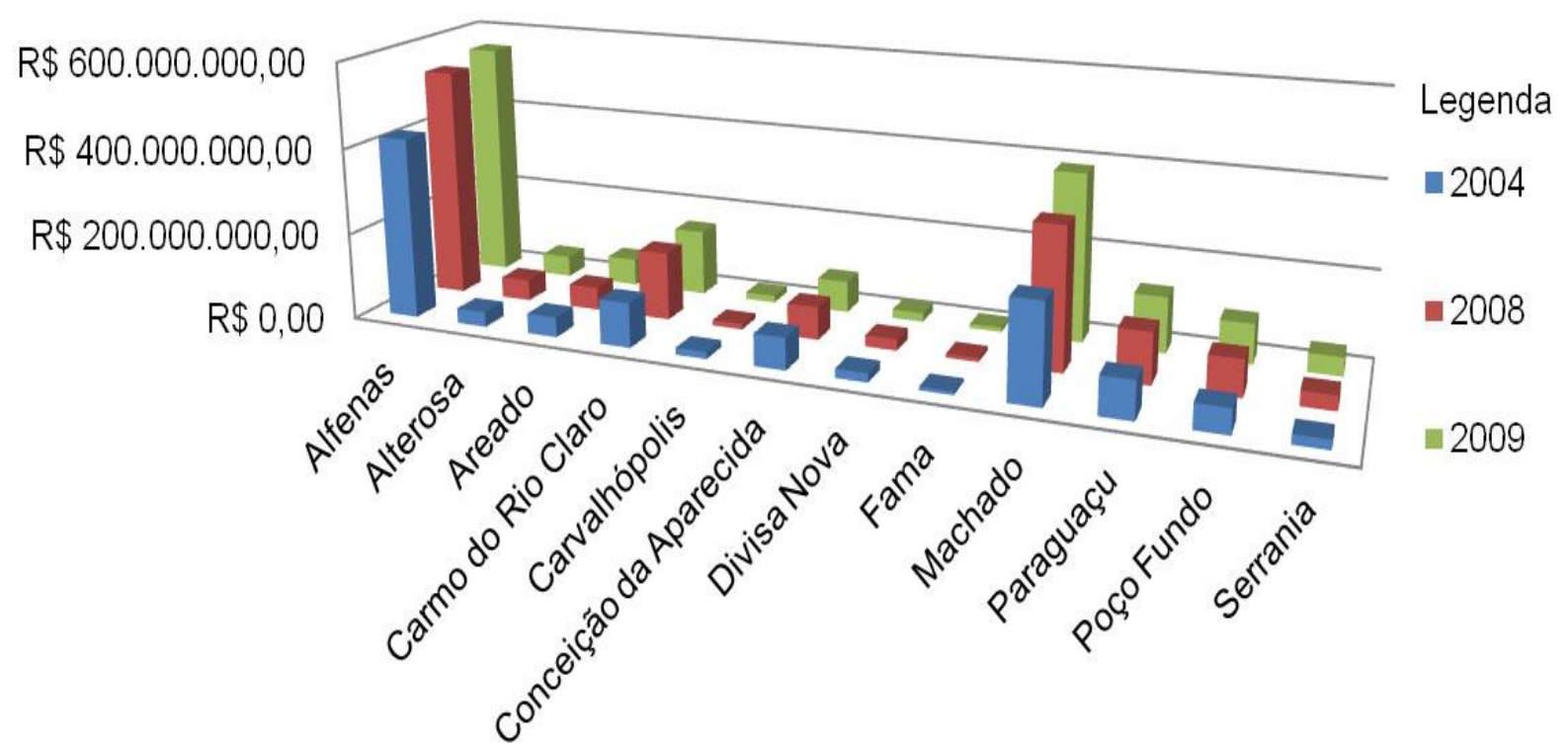

Adaptado de: Divisão de Assuntos Municipais - DICAC/SAIF/SEF-MG e Relatório RFGA 1350. Notas: Valor 2004 para repasse de ICMS em 2006 - Resolução № 3.735 de 30-12-05; Valor 2008 para repasse de ICMS em 2010 - Resolução № 4.205 de 15-04-10, publicada em 16-04-10; Valor 2009 para repasse de ICMS em 2011- Resolução № 4.279 de 23-12-10, publicada em 24-12-10. 
Outra questão observada, Gráfico 4, reflete que toda a produção da microrregião não acompanha, está absurdamente desigual, o ritmo de crescimento econômico das cidades como Varginha, Pouso Alegre e Poços de Caldas, revelando um desequilíbrio econômico perverso que se territorializa sobre o Estado de Minas Gerais que dificilmente ${ }^{8}$ a Lei 18.030 conseguirá reverter essas desigualdades.

Gráfico 4 - Comparação entre os Valores Adicionados Fiscais. Ano base 2004 a 2009.

\section{Montante VAF}

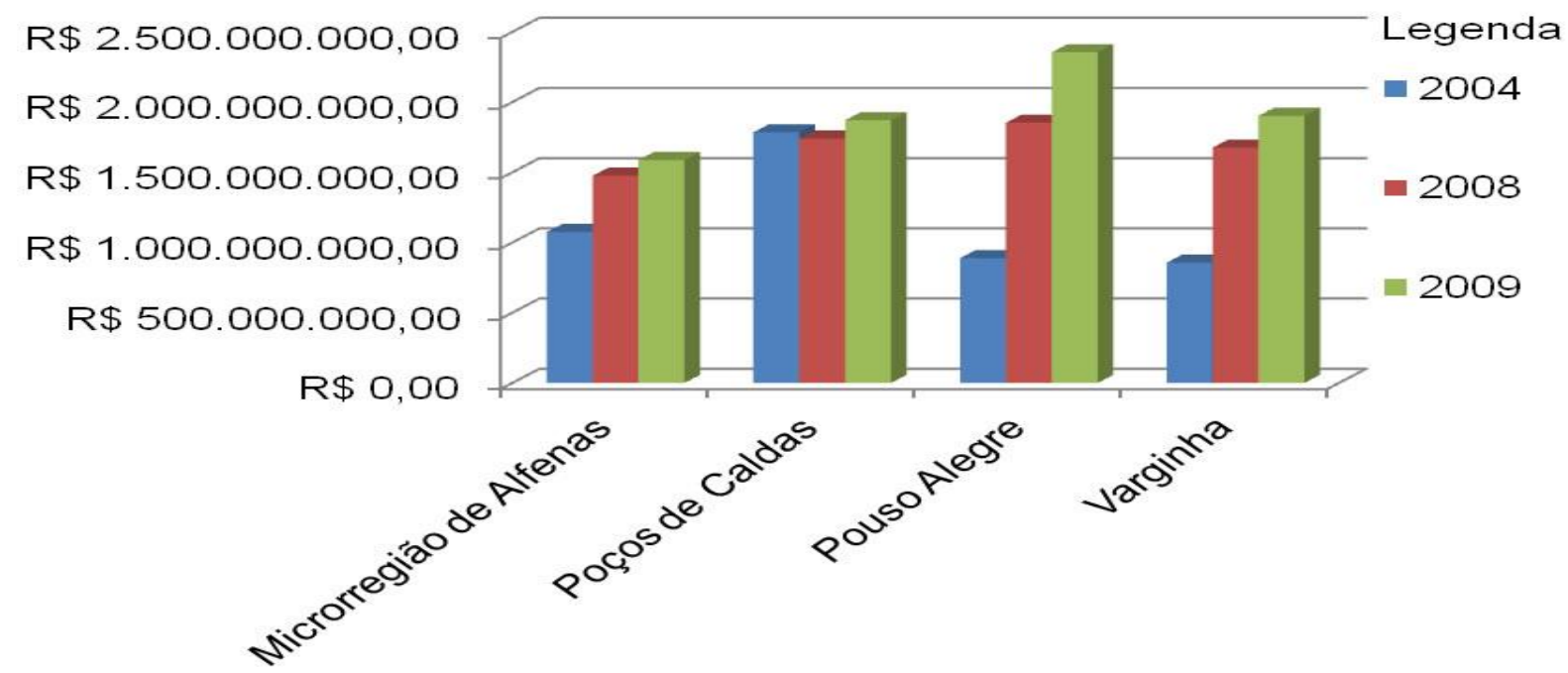

Adaptado de: Divisão de Assuntos Municipais - DICAC/SAIF/SEF-MG e Relatório RFGA 1350. Notas: Valor 2004 para repasse de ICMS em 2006 - Resolução № 3.735 de 30-12-05; Valor 2008 para repasse de ICMS em 2010 - Resolução № 4.205 de 15-04-10, publicada em 16-04-10; Valor 2009 para repasse de ICMS em 2011- Resolução № 4.279 de 23-12-10, publicada em 24-12-10.

As maiores contratações de funcionários seguem padrões de mão de obra como trabalhadores ao cultivo de café, trabalhadores agropecuários em geral, vendedores de comércio varejista, servente de obras, pedreiros, auxiliares de escritório em geral, motoristas de caminhão - rotas regionais e internacionais - e entre outros. Mais a fundo, ao analisar dados da Fundação João Pinheiro (2008), se constata que os municípios possuem especializações quanto ao emprego de suas atividades econômicas. Da análise da Tabela 1 se observa que o setor agropecuário tem empregado mais pessoas em Serrania, Conceição da Aparecida e Carmo do Rio Claro e também o contraste que há na concentração de disponibilidade de

\footnotetext{
${ }^{8}$ Conclusão feita após a leitura dos trabalhos de AMARAL et. al., 2006; PRATES, 2010; ROSADO et. al., 2009.
} 
empregos para as cidades de Machado, Alfenas e Paraguaçu, onde os setores mais valorizados economicamente se concentram em serviços e indústria. Nessa disputa por domínio de ofertas de empregos, Areado apresentou o pior desempenho em termos de variação do estoque de ocupados no setor formal, sendo sua variação média negativa anual de $0,7 \%$, e os que tiveram os melhores desempenhos foram Conceição da Aparecida (9,1\%), Divisa Nova (7,4\%) e Poço Fundo (6,0\%). Porém, a microrregião de Alfenas se situa entre as que apresentaram crescimento de ocupação abaixo da média de Minas Gerais (FUNDAÇÃO JOÃO PINHEIRO, 2008).

Tabela 1 - Distribuição e Taxa de Variação Anual do Emprego Formal microrregião de Alfenas $-2006^{9}$.

\begin{tabular}{|c|c|c|c|c|c|c|c|c|}
\hline \multirow[b]{2}{*}{ Municípios } & \multicolumn{6}{|c|}{ Setor de atividade econômica (\%) } & \multirow{2}{*}{$\begin{array}{c}\% \text { do } \\
\text { total do } \\
\text { emprego }\end{array}$} & \multirow{2}{*}{$\begin{array}{c}\text { VM } \\
\text { Anual } \\
(\%)^{*}\end{array}$} \\
\hline & Ind. & $\begin{array}{c}\text { Const. } \\
\text { Civil }\end{array}$ & Comércio & Serviços & Agro. & $\begin{array}{c}\text { Total } \\
\text { (Absoluto) }\end{array}$ & & \\
\hline Alfenas & 13,6 & 2,8 & 21,2 & 48,0 & 14,3 & 14.268 & 40,8 & 4,1 \\
\hline Alterosa & 7,6 & 0,4 & 13,6 & 60,9 & 17,5 & 990 & 2,8 & 4,8 \\
\hline Areado & 4,7 & 6,5 & 21,4 & 41,7 & 25,7 & 1.260 & 3,6 & $-0,7$ \\
\hline Carmo do Rio & 8,9 & 1,5 & 17,8 & 31,7 & 40,2 & 2.736 & 7,8 & 4,6 \\
\hline Carvalhópolis & 20,6 & 0,0 & 9,3 & 59,1 & 11,0 & 364 & 1,0 & 6,4 \\
\hline $\begin{array}{c}\text { Conceição da } \\
\text { Aparecida }\end{array}$ & 2,1 & 0,0 & 16,8 & 37,4 & 43,7 & 1.020 & 2,9 & 9,1 \\
\hline Divisa Nova & 0,9 & 0,4 & 10,9 & 51,4 & 36,8 & 541 & 1,5 & 7,4 \\
\hline Fama & 4,7 & 1,2 & 4,0 & 53,3 & 37,6 & 274 & 0,8 & 2,1 \\
\hline Machado & 25,3 & 1,9 & 18,0 & 30,1 & 25,5 & 7.648 & 21,9 & 2,5 \\
\hline Paraguaçu & 44,5 & 1,9 & 15,6 & 23,3 & 14,8 & 3.350 & 9,6 & 4,6 \\
\hline Poço Fundo & 24,8 & 0,7 & 20,7 & 41,3 & 12,6 & 1.311 & 3,8 & 6,0 \\
\hline Serrania & 18,2 & 0,2 & 5,3 & 23,5 & 52,8 & 1.191 & 3,4 & 5,3 \\
\hline $\begin{array}{l}\text { Total da } \\
\text { Microrregião }\end{array}$ & 18,3 & 2,0 & 18,4 & 39,4 & 22,0 & 34.953 & 100,0 & 3,9 \\
\hline
\end{tabular}

${ }^{\star}$ Taxa de Variação Média Anual entre os anos 2000 e 2006.

Fonte de dados: Ministério do Trabalho e Emprego (MTE), Relação Anual de Informações Sociais (RAIS).

Por outro lado, é visível que as concessões de benefícios às empresas vão além das perversidades (VARSANO, 1997). Da entrevista com o secretário de desenvolvimento econômico e ação regional de Alfenas foi possível concluir que,

\footnotetext{
${ }^{9}$ Vale lembrar que para os anos de 2005 e 2006 os municípios de Carvalhópolis e Paraguaçu receberam algumas indústrias e empresas do setor de serviços. Para o primeiro, o contingente populacional altera significamente o percentual do estoque de ocupados, uma vez que, por exemplo, bastaria uma indústria ou empresa contratar 50 pessoas para alterar e elevar a porcentagem relativa aos demais setores econômicos. Ao município de Carvalhópolis foi identificada a vinda de algumas indústrias ligadas ao setor de beneficiamento de produtos agroindustriais; como a produção e distribuição de leite pasteurizado, a presença de uma referente à produção de carvão vegetal e outra à produção de vassouras e espanadores.
} 
das onze maiores ${ }^{10}$, sete empresas possuem alguma forma de benefício por parte da prefeitura municipal de Alfenas ${ }^{11}$ e se constata que da análise do tributo IPTU concedido a duas empresas, valores juntos calculados, representam ausências tributárias de aproximadamente 190.000 Reais por ano. Também foi possível observar, durante as atividades em campo, que a vinda de empreendimentos corporativos gera pressões às infraestruturas da cidade, como maior fluxo de veículos e pessoas às vias inter e intraurbanas, migração de mão de obra entre as cidades $^{12}$ e aumento dos custos locais, como aluguéis. Todas essas características operam a concluir que a vinda de empresas às localidades pode não gerar os efeitos esperados à economia local. Assim, por detrás de um discurso em favor dos incentivos fiscais, visto como benéficos para toda a sociedade, pode-se esconder um privilégio perverso a um pequeno grupo econômico.

Por esses e outros comportamentos, a dúvida acerca das vantagens sociais dos benefícios fiscais e territoriais é notória, tem-se em vista que o ganho social, geração de emprego e renda, pode ser menor que o benefício atribuído ao agente econômico - desoneração tributária, provocando desequilíbrio entre os sistemas de produção e trabalho das localidades.

Por fim, vale lembrar que a aplicação da prática de renúncia fiscal, nos moldes como vêm sendo praticados, onera as pequenas empresas de forma regressiva, que, ao custo da expansão e demanda por serviços que as grandes

\footnotetext{
${ }^{10}$ Estudadas em 2011 e com base no VAF 2009 junto à Secretaria de Estado da Fazenda de Minas Gerais.

${ }^{11}$ Das 9 empresas que vieram para a cidade de Alfenas, de 2009 para 2011, 3 ganharam isenção de tributos municipais - IPTU, ISSQN, Taxa de Resíduos Sólidos (TRS), Taxa de Alvará e Funcionamento e Licença de Localização, 1 está à espera de doação de terreno e 6 ganharam terreno. A maior parte das indústrias que faz comércio com outras localidades tem pretensões em construir suas unidades ao longo da rodovia BR491, das 9 empresas, 5 foram para o distrito industrial. Também é possível notar que quanto maior for os investimentos corporativos, maiores serão os benefícios concedidos, das 9 empresas, 4 se comprometeram a empregar em média de 15 a 25 trabalhadores e irão receber apenas doações de terrenos, enquanto empresas que pretendem contratar de 40 pessoas a 60 pessoas e investir valores acima de 10 milhões de Reais receberam auxílio burocrático, benefícios fiscais e preparações de terreno, como limpeza, por parte da prefeitura. Entretanto, alguns pontos chamam a atenção, uma empresa de alimentos que irá gerar números em torno de 80 a 90 empregos recebeu apenas doação de terreno ao distrito industrial, enquanto duas grandes empresas locais há muitos anos instaladas em Alfenas irão receber, somente a partir de 2012, alguma forma de incentivo fiscal ao auxilio às suas expansões que foram feitas em anos anteriores, com recursos próprios.

${ }_{12}$ Sobre esse assunto, Augusto e Fausto (2006) concluem que as grandes trocas populacionais ocorreram entre as microrregiões de Santa Rita do Sapucaí e Pouso Alegre, seguidas de Alfenas e Poços de Caldas, bem como entre Alfenas e Varginha. $O$ autor confere às trocas migratórias internas das microrregiões os maiores números devido à proximidade entre as cidades, assim as populações migram a encontrar esperança em outros territórios para a conquista de emprego e melhoria financeira, por exemplo.
} 
empresas provocam, geram significativos impactos ao reordenamento do território. Nesse aspecto, o Poder Público espera mobilizar os recursos financeiros recolhidos em prol da melhoria social, porém se esquece que para isso ocorrer será necessário um pacote tributário que atenda às novas demandas por serviços, como transportes, melhoria no sistema viário, dar respostas à expansão no uso e ocupação do solo e entre outros. Ao custo da socialização das melhorias e mudanças, infelizmente, a população local responde financeiramente por meio do pagamento do Imposto Predial e Territorial Urbano. Às empresas domésticas e de médio a pequeno porte fica mais um gasto, além do pagamento do IPTU, através da cobrança do Imposto Sobre Serviços de Qualquer Natureza, renunciados às grandes corporações ${ }^{13}$ (NASCIMENTO, 2008).

\section{CONSIDERAÇÕES FINAIS}

Ibañez (2006) e Prado e Cavalcanti (2000) demonstraram em suas pesquisas que a renúncia fiscal às empresas é prejudicial ao planejamento do território. Não diferente desses autores e diversos outros pesquisadores que concentram reflexões aos resultados do desenvolvimento desigual entre as localidades ${ }^{14}$, o observado nesta pesquisa resgata o conceito de alienação do território (SANTOS, 2000) que, surpreendentemente, dota a territorialidade (RAFFESTIN, 1993; SANTOS, 1999a)

\footnotetext{
${ }^{13}$ A arrecadação de Alfenas aumentou $86 \%$ nos últimos quatro anos. Em 2004 foram arrecadados $\mathrm{R} \$$ 58 milhões, $2008 \mathrm{R} \$ 108$ milhões e 2009 foi de R\$ 137 milhões. O Secretário Municipal da Fazenda de Alfenas, Salomar Júnior de Carvalho, lembra que o aumento foi conseguido sem que o município criasse novos impostos e em muitos casos até reduzindo os valores. Foi o que aconteceu em bairros como Pinheirinho, Jardim Primavera, Recreio Vale do Sol, Santa Clara, Santa Luzia, Campos Elíseos e Santos Reis, que tiveram redução de até $30 \%$ no IPTU sobre os imóveis construídos. Cerca de 7.500 famílias foram beneficiadas. De acordo com o secretário, o crescimento é resultado da confiança do contribuinte no Governo Municipal. "A população percebe as melhorias que estão sendo feitas na cidade nas diversas áreas e retribuem pagando os impostos". Ele lembra ainda que a inadimplência histórica na cidade caiu para pouco mais de $11 \%$. De $48 \%$ para $36 \%$ em quatro anos. Foram campanhas de conscientização, criação de uma central que entra em contato com o contribuinte inadimplente e a anistia, que só em 2008 arrecadou cerca de $R \$ 1,3$ milhão. $A$ arrecadação da dívida ativa em 2004 foi de $R \$ 2,1$ milhões e no ano de $2003 R \$ 6,1$ milhões. $O$ secretário cita também o ISSQN, imposto pago pelas empresas prestadoras de serviços ao município, o aumento nos quatro anos foi de $152 \%$. A arrecadação desse imposto quase empatou com o IPTU, a maior fonte própria do município. "Nas cidades maiores é normal que a arrecadação do ISSQN seja maior que a do IPTU. Em Alfenas as causas do aumento são a fiscalização atuante e a instalação de novas empresas na cidade". O secretário afirma ainda que a arrecadação do IPTU em Alfenas é quase igual às cidades maiores da região, como Varginha e Pouso Alegre.

${ }^{14}$ Exemplos: SANTOS, 1999b, 2000; FURTADO, 1992; ARAUJO, 2000a, 2000b; RICUPERO, 2000; BRANDÃO, 2007; SANTOS e SILVEIRA, 2001; BECKER e EGLER, 1993; CANO 1998; SOJA, 1993; ROSADO et. al., 2009; DULCI, 2002.
} 
como instrumento para a obtenção da maior mais-valia pelo empreendedor em detrimento das desigualdades espaciais (SOJA, 1993; DULCI, 2002; VARSANO, 1997), uma vez que os estudos sobre a microrregião de Alfenas apontam para essa inclinação de pensamento.

Diante das tendências produtivas (SANTOS, 1999b, 1997) entre as cidades, a conclusão revela uma política fiscal perversa que dá seguimento à guerra fiscal e dos lugares (IBAÑEZ, 2006) para o aumento de suas receitas econômicas, que ampliam as desigualdades regionais, municipais e sociais. Discursos como o do secretário do desenvolvimento econômico e ação regional da prefeitura de Alfenas, que reclama a renúncia fiscal às empresas em troca de suas vindas e instalações, têm se territorializado sobre todos os municípios da região sul de Minas.

Conclui-se que se faz necessário um programa de desenvolvimento regional integrado para se evitar que ocorram aglomerações ou pontos luminosos localizados de desenvolvimentos sociais e econômicos. Para os empresários que desejarem instalar suas unidades fabris na microrregião de Alfenas, percebem-se ganhos significativos de mais-valia diante da situação verificada, pois contam com fortes atrativos: renúncias fiscais e ajuda de prefeituras ao custeio de infraestruturas, doações de terrenos e, além disso, com grande parcela da população que recebe entre 1 a 2 salários mínimos e apta a trabalhar por menores salários, conforme se verificou dos dados referentes à renda média para a microrregião ${ }^{15}$.

Espera-se um fim para a guerra entre as cidades da microrregião de Alfenas, porque todas têm a perder neste conflito pelo maior aumento de suas fontes de receita econômica. Juntos podem elevar seus potenciais e fazer deles muitas melhorias para a microrregião, como uma hidrovia funcional para o escoamento de mercadorias ou integrar suas produções de modo que as indústrias consigam um preço favorável ao beneficiamento de produtos agroindustriais, por meio de auxílios tributários entre os municípios e não de intenções generalizadas de renúncias fiscais. Da maneira como está sendo observada a guerra fiscal e dos lugares, caso continue, só restará à microrregião de Alfenas a continuar perder investimentos, em face do crescimento e desenvolvimento econômico e social de Poços de Caldas, Varginha e Pouso Alegre.

\footnotetext{
${ }^{15}$ BRASIL/MTE. Relatórios Anuais de Informação Sociais (RAIS/CAGED). Brasília: Ministério do Trabalho e Emprego, 2006-2009.
} 


\section{REFERÊNCIAS BIBLIOGRÁFICAS}

ALONSO, M. O que se entende por princípio da territorialidade no Direito Tributário? $2010 . \quad$ Disponível em: $<$ http://www.lfg.com.br/public html/article.php?story=20100115182453428\&mode=pri nt>. Acesso em: 4/01/2011.

ARAUJO, T. B. Herança de diferenciação e futuro de fragmentação. Revista Estudos Avançados, São Paulo, v. 11, n. 29, p.7-36, jan./abr., 1997.

Dinâmica regional brasileira nos anos noventa: rumo à desintegração competitiva? In: CASTRO, I. E.; MIRANDA, M.; EGLER, C. A. G. (orgs), Redescobrindo o Brasil 500 anos depois. Rio de Janeiro: Bertrand Brasil, 2000a, p. 73-91.

Ensaios sobre o desenvolvimento brasileiro: heranças e urgências. Rio de Janeiro: Revan; Fase, 2000b.

AUGUSTO, H. A.; FAUSTO, B. Migrações em Minas Gerais: tendências recentes a partir da análise de suas microrregiões. In: XII Seminário sobre a Economia Mineira, 2006, Diamantina. In: Anais de Economia, História, Demografia e Políticas Públicas. Belo Horizonte: CEDEPLAR/UFMG, 2006. Disponível em: <http://www.cedeplar.ufmg.br/seminarios/seminario diamantina/2006/D06A064.pdf>.

BECKER, B.; K.; EGLER, C. A. G. Brasil: uma nova potência regional na economia-mundo. Rio de Janeiro: Bertrand Brasil, 1993.

BENKO, G. Economia, espaço e globalização: na aurora do século X. São Paulo: Hucitec, 1999.

BRANDÃO, C. A. Território e desenvolvimento: as múltiplas escalas entre o local e o global. Campinas: Unicamp, 2007.

BRASIL. Instituto Brasileiro de Geografia e Estatística - IBGE. Produto Interno Bruto dos municípios 2003 - 2007. 2010a. Disponível em:

$<$ http://www.ibge.gov.br/home/estatistica/economia/pibmunicipios/2003 2007/default. shtm>. Acesso em 22/06/2011.

Contagem da população 2007. 2010b. Disponível em: <http://www.ibge.gov.br/home/estatistica/populacao/contagem2007/default.shtm>. Acesso em 15/07/11.

CANO, W. Desequilíbrios regionais e concentração industrial no Brasil. Campinas: Unicamp, 1998. 
CASTILLO, R. A. Região competitiva e logística: expressões geográficas da produção e da circulação no período atual. In: Anais do IV Seminário Internacional sobre Desenvolvimento Regional. Santa Cruz do Sul: UNISC, v. 1, 2008.

CASTILLO, R.; FREDERICO, S. Dinâmica Regional e Globalização: espaços competitivos agrícolas no território brasileiro. Revista Mercator, Fortaleza, v. 09, p. 17-26, jan./abr., 2010.

DANIEL, C. Poder Local no Brasil urbano. Revista Espaços \& Debates, São Paulo, Núcleo de Estudos Regionais e Urbanos (NERU), v. Ano VIII, n. 24, p.26-39, 1988.

DINIZ, C. C. Desenvolvimento poligonal no Brasil: nem desconcentração, nem contínua polarização. Revista Nova Economia, Belo Horizonte, v. 03, n. 1, set., 1994.

DULCl, O. S. Guerra fiscal, desenvolvimento desigual e relações federativas no Brasil. Revista Sociologia e Política, Curitiba, n. 18, p. 95-107, jun., 2002.

FIGUEIREDO, A. T. L.; DINIZ, C. C. Distribuição regional da indústria mineira. Revista Nova Economia, Belo Horizonte, v. 10, n. 2, p. 39-69, dez., 2000.

FREDERICO, S. Formação territorial de Minas Gerais. 2009. Disponível em: $<$ http://enhpgii.files.wordpress.com/2009/10/samuel-frederico.pdf>. Acesso em $01 / 06 / 2010$.

FUNDAÇÃO JOÃO PINHEIRO. Mapa do mercado de trabalho: estrutura e evolução da ocupação formal em Minas Gerais. Belo Horizonte: Fundação João Pinheiro - Centro de Estatística e Informação, 2008. Disponível em: $<$ http://www.fjp.gov.br/index.php/component/docman/doc download/74-mapa-do mercado-de-trabalho-em-minas-gerais-2000-2006>.

FURTADO, C. Brasil: a construção interrompida. 2 ed., Rio de Janeiro: Paz e Terra, 1992.

GARCIA, M. A. Integração e projeto nacional de desenvolvimento. In: LAVINAS, L.; CARLEIAL, L.; NABUCO, M.R. Integração, Região e Regionalismos. Rio de Janeiro: Bertrand Brasil, 1994, v.1, p. 27-40.

HAESBAERT, R. O mito da desterritorialização: do "fim dos territórios" à multiterritorialidade. Rio de Janeiro: Bertrand Brasil, 2004.

IBAÑEZ, P. Território e Guerra Fiscal: a perversidade dos incentivos territoriais. 2006. 300f. Dissertação (Mestrado em Geografia Humana) - Faculdade de Filosofia, Letras e Ciências Humanas. Departamento de Geografia, Universidade de São Paulo, São Paulo. 2006.

LAVINAS, L.; CARLEIAL. L.; NABUCO, M. R. Integração, Região e Regionalismos. Rio de Janeiro: Bertrand Brasil, 1994, v.1. 
MATOS, P. O. Análise dos Planos de Desenvolvimento elaborados no Brasil após o II PND. 2002. 184f. Dissertação (Mestrado em Economia Aplicada) - Escola Superior de Agricultura, Universidade de São Paulo, Piracicaba. 2002.

MINAS GERAIS - Assembleia Legislativa de Minas Gerais - ALMG. Receita Tributária - ICMS Solidário. 2011. Disponível em: $<$ www.almg.gov.br/.../2011/.../tema4 receita tributaria.pdf $>$. Acesso em: 09/11/2011.

NASCIMENTO, S. P. Guerra fiscal: uma avaliação comparativa entre alguns estados participantes. Revista Economia Aplicada, Ribeirão Preto, v.12, n.4, p. 677-706, out./dez., 2008

PASSOS, M. M.; MORO, D. A. A geografia e as lógicas regionais. Revista Boletim de Geografia, Maringá, v. 21, n. 1, p. 1-12, 2003.

PORTER, M. E. Vantagem competitiva: criando e sustentando um desempenho superior. Rio de Janeiro: Campus, 1990.

PRADO, S.; CAVALCANTI, E.G. C. A guerra fiscal no Brasil. Brasília: IPEA; São Paulo: FUNDAP/FAFESP, 2000.

PRATES, A. A Dinâmica da Estrutura Produtiva da Região Sul/Sudoeste de Minas Gerais nos Anos Recentes. In: XII SEMINÁRIO SOBRE A ECONOMIA MINEIRA, 2010, Diamantina. In: Anais de Economia, História, Demografia e Políticas Públicas. Belo Horizonte: CEDEPLAR/UFMG, 2010. Disponível em: $<$ http://www.cedeplar.ufmg.br/seminarios/seminario diamantina/2010/D10A054.pdf >.

PREFEITURA MUNICIPAL DE ALFENAS. Alfenas é exemplo em capacitação profissional. $2011 . \quad$ Disponível em: $<$ http://www.alfenas.mg.gov.br/noticias.asp?act=noticias\&act2=ver\&id=1495 $>$.

Acesso em: 25/11/2011.

RAFFESTIN, C. Por uma Geografia do Poder. São Paulo: Ática, 1993.

RICUPERO, R. Integração externa, sinônimo de desintegração interna? Revista Estudos Avançados, São Paulo, v. 14, n. 40, p. 13-22, set./dez., 2000.

ROSADO, P. L.; ROSSATO, M. V.; LIMA, J. E. Análise do desenvolvimento socioeconômico das microrregiões de Minas Gerais. Revista Econômica do Nordeste, Fortaleza, v. 40, n. 2, p. 175-184, abr./jun., 2009.

ROSENDAHL, Z. Território e territorialidade: uma perspectiva geográfica para o estudo da religião. In: ROSENDAHL, Z.; CORRÊA, R. L. (orgs.). Geografia: temas sobre cultura e espaço. Rio de Janeiro: EDUERJ, 2005, p. 191-226. 
QUARESMA, S. J.; BONI, V. Aprendendo a entrevistar: como fazer entrevistas em Ciências Sociais. Revista Eletrônica dos Pós-Graduandos em Sociologia Política da UFSC, Florianópolis, v. 2, n. 1 (3), p. 68-80, jan./jul., 2005.

SANTOS, M. A. Espaço e Sociedade. Petrópolis: Vozes, 1979.

O retorno do território. In: SANTOS, M. A.; SOUZA, M. A. A.; SILVEIRA, L. M. (Org.). Território: Globalização e Fragmentação. São Paulo: Hucitec; Anpur, 1994, p. 15-20.

. Da política dos Estados à política das empresas. Cadernos da Escola do Legislativo, Belo Horizonte, v. 3, n. 6, p. 9-23, jul./dez., 1997.

A Natureza do Espaço: espaço e tempo, razão e emoção. 3. ed. São Paulo: Hucitec, 1999a.

Modo de produção técnico-científico e diferenciação espacial. Revista Território, Rio de Janeiro, v. Ano VI, n. 6, p. 5-20, 1999b.

Guerra dos Lugares. Jornal Folha de São Paulo, São Paulo, 08 ago. 1999c.

Por uma outra globalização. Do pensamento único à consciência universal. Rio de Janeiro; São Paulo: Record, 2000.

SANTOS. M., A.; SILVEIRA, M. L. O. Brasil: Território e Sociedade no início do século XXI. Rio de Janeiro: Record, 2001.

SAQUET, M. A. Abordagens e concepções sobre território. São Paulo: Expressão Popular, 2007.

SOJA, E. Geografias pós-modernas. Rio de Janeiro: Jorge Zahar Editor, 1993.

STEVENSON, W. J. Administração das operações de produção. Rio de Janeiro: LTC, 2001.

TOLEDO, L. A.; GALVÃO, D. da S. P.; NAGAI, R.; BRAGHETTA, M. B.; TRUITE, R. A decisão estratégica da localização e o surgimento dos tecnopólos: o caso de São José dos Campos. Revista de Administração Mackenzie, São Paulo, v.8, n. 3, p.11-31, set./dez., 2007.

VARSANO, R. A guerra fiscal do ICMS: quem ganha e quem perde. Revista Planejamento e Políticas Públicas, Brasília: IPEA, n.15, p. 13-18, jun.,1997.

Entidades Consultadas:

ASSOCIAÇÃO DOS MUNICÍPIOS DO LAGO DE FURNAS - ALAGO: $<\underline{\text { http://www. alago.org.br/>. }}$ 
FUNDAÇÃO JOÃO PINHEIRO: <www.fjp.gov.br/>.

\section{FEDERAMINAS:}

$<$ http://www.federaminas.org.br/index.php?pagina=detalhe noticias\&cod=398 $>$.

INSTITUTO BRASILEIRO DE GEOGRAFIA E ESTATÍSTICA: $<$ http://www.ibge.org.br/>.

SEBRAE/MG: <www.sebraemg.com.br/>.

SECRETARIA DE ESTADO DA FAZENDA DE MINAS. Análise Econômico Financeira. Receita do Estado. Disponibilidade e acesso: $<$ http:\|www.sef.mg.gov.br>.

SECRETARIA DE ESTADO DA FAZENDA DE MINAS. Assuntos Municipais - Valor Adicionado Fiscal - VAF. Disponibilidade e acesso: <http:llwww.sef.mg.gov.br>.

(Recebido em 16.12.2011. Aceito em 19.03.2012) 